\title{
Exclusion of two candidate loci for autosomal recessive nemaline myopathy
}

\author{
Esa Tahvanainen, Alan H Beggs, Carina Wallgren-Pettersson
}

Department of

Medical Genetics, University of Helsinki. PO Box 21, 00014 Helsinki, Finland

E Tahvanainen

C Wallgren-Pettersson

Harvard Medical School, Genetics Division, Children's Hospital, 300

Longwood Avenue, Boston, MA 02115, Boston

A H Beggs

Correspondence to Dr Tahvanainen

Received 19 May 1993 Accepted for publication 10 June 1993
Haartmaninkatu 3,

\begin{abstract}
The putative gene for autosomal recessive nemaline myopathy has not been mapped, cloned, or otherwise characterised. We used linkage analysis with polymorphic CA repeats to test for the involvement of two candidate loci, APOA2 and ACTN2. Based on the segregation in five families both candidate loci could be excluded. ( $₹$ Med Genet 1994;31:79-80)
\end{abstract}

Congenital nemaline myopathy (CNM), first described in 1963 by Conen et al ${ }^{1}$ and Shy et $a l,{ }^{2}$ exists in an autosomal recessive and an autosomal dominant form. ${ }^{34}$ Both are characterised by generalised muscle weakness and

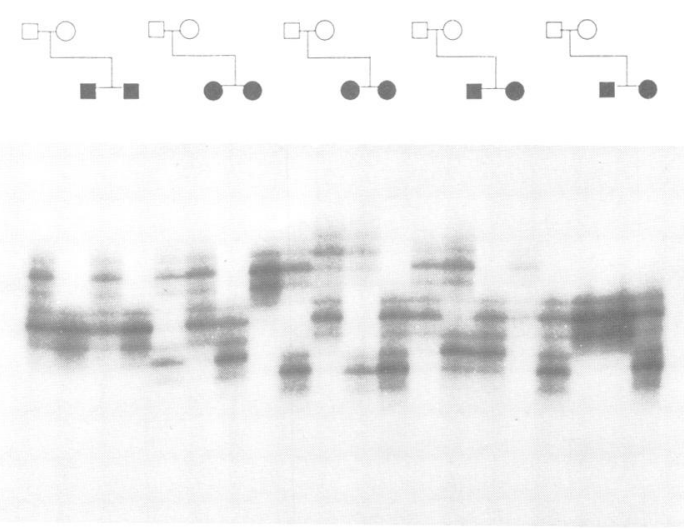

Alleles APO A2
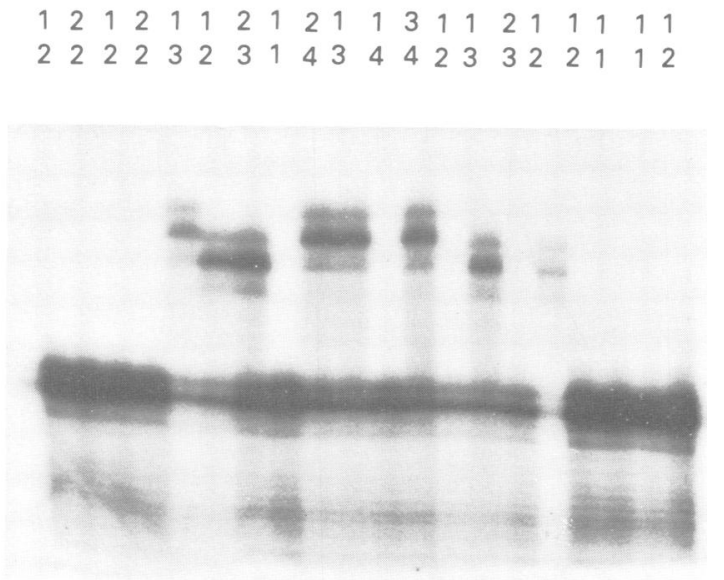

Alleles ACTN2

$\begin{array}{llllllllllllllllllll}1 & 1 & 1 & 1 & 1 & 2 & 2 & 3 & 1 & 1 & 2 & 1 & 2 & 1 & 2 & 1 & 1 & 1 & 1 & 1\end{array}$ $\begin{array}{llllllllllllllllllll}1 & 1 & 1 & 1 & 3 & 3 & 3 & 3 & 2 & 2 & 2 & 2 & 2 & 2 & 2 & 2 & 1 & 1 & 1 & 1\end{array}$

Autoradiographs of the $C A$ repeat polymorphisms $A P O A 2$ (above) and ACTN2 (below). The pedigrees are aligned with the lanes in the autoradiographs. Numbered allele designations are shown below each lane. Recombinations between marker and disease phenotype are seen in all families for APOA2 and in three families for ACTN2. nemaline bodies in the muscle fibres. Laing et $a l^{5}$ suggested linkage of the gene for the autosomal dominant form to chromosome 1 in a large Australian family with a maximum lod score of 3.8 at zero recombination for the polymorphic marker APOA2. As far as we know no linkage studies have been published to date on the autosomal recessive form.

$\alpha$-actinin is regarded as a major constituent of the nemaline bodies. ${ }^{6}$ Therefore, the genes for human muscle specific $\alpha$-actinin, ACTN2 on chromosome 1q42-q43 and ACTN3 on chromosome 11q13-q14, have been suggested as candidate genes for CNM. ${ }^{7}$ These genes have been cloned but an intragenic polymorphism is only available for ACTN2.

We studied five families, each with two children affected by autosomal recessive CNM. Three of the families were Finnish, ${ }^{9}$ one Welsh, and one Danish. All 10 patients showed a clinical picture consistent with CNM: the muscle weakness was most pronounced in the face, the flexors of the neck and trunk, the dorsiflexors of the feet, and the extensors of the toes. All showed nemaline bodies and predominance of type 1 fibres in their muscle biopsies, except for the sister of one of the index cases, who had a clinical picture identical to that of her affected brother and did not undergo muscle biopsy.

DNA from blood lymphocytes of the patients and their parents were studied with an intragenic ACTN2 ${ }^{8}$ and an APOA2 $2^{10} \mathrm{CA}$ repeat polymorphism. Microsatellite PCR conditions for a reaction volume of $10 \mu \mathrm{l}$ were as follows: $30 \mathrm{ng}$ target DNA, 0.3 units Dynazyme DNA polymerase (Finnzymes, Espoo, Finland), $25 \mathrm{ng}$ primers ACTN2 or APOA2, $10 \mathrm{mmol} / 1$ Tris- $\mathrm{HCl}\left(\mathrm{pH} 8.8\right.$ at $\left.20^{\circ} \mathrm{C}\right)$, $1.5 \mathrm{mmol} / 1 \mathrm{MgCl}_{2}, 50 \mathrm{mmol} / 1 \mathrm{KCl}, 0.1 \%$ Triton $\mathrm{X}-100,200 \mu \mathrm{mol} / 1 \mathrm{dATP}, \mathrm{dGTP}$, and dTTP, $3 \mu \mathrm{mol} / 1$ dCTP, and $0.7 \mu \mathrm{Ci} \alpha$ ${ }^{32} \mathrm{P}$ dCTP (3000 Ci/mmol, Amersham). The reactions were overlaid with mineral oil and temperature cycling conditions were as follows: $94^{\circ} \mathrm{C}$ for three minutes to denature, followed by 30 cycles at $94^{\circ} \mathrm{C}, 55^{\circ} \mathrm{C}$, and $72^{\circ} \mathrm{C}$ each for one minute, with the final elongation time extended to five minutes. The reaction products were mixed with an equal volume of formamide loading buffer, $5 \mu \mathrm{l}$ aliquots were electrophoresed on standard $6 \%$ denaturing sequencing gels, and autoradiographs were made using $x$ ray film. Lod scores were calcu- 
lated by the MLINK program of the LINKAGE package. ${ }^{11}$

For CA marker ACTN2 three families showed recombination between the marker and the disease gene (figure), two families were uninformative, and the lod score at a recombination fraction of 0.01 was -3.62 . All families showed recombination between marker APOA2 and the disease gene, the lod scores being -7.83 at a recombination fraction of 0.01 and -2.23 at 0.1 .

We conclude that ACTN2 is not the gene causing autosomal recessive CNM and the disease gene does not segregate with the locus APOA2.

The authors are grateful to Professor Albert de la Chapelle, Tepartment of Medical Genetics, University of Helsinki, for Department of Medical Genetics, University of Helsinki, for critical reading of the manuscript, to Dr Helen Hughes, Institute of Medical Genetics, University of Wales College of Medicine, for providing facilities to study the Welsh family, to Professor R H T Edwards and Dr Tim Helliwell, University of Liverpool, UK, for studying the muscle biopsies of the Welsh patients, to Dr Flemming Juul Hansen, University Hospital Section of Neuropaediatrics, Copenhagen, Denmark, for providing facilities to study the Danish family, and Nigel Laing Australian Neuromuscular Research Institute, Department of Pathology, QEII Medical Centre, Nedlands, Australia, fo helpful discussions. Dr Alan $\mathrm{H}$ Beggs was supported in part by the Charles $\mathbf{H}$ Hood Foundation, Boston, Massachusetts and Dr Carina Wallgren-Pettersson by the Finska Läkaresällskapet, Finland.
1 Conen PE, Murphy EG, Donohue WL. Light and electron microscopic studies of 'myogranules' in a child with hypotonia and muscle weakness. Can Med Assoc $f$ 1963;89:983-6.

2 Shy GM, Engel WK, Somers JE, Wanko T. Nemaline myopathy. A new congenital myopathy. Brain 1963;86:793-810.

3 McKusick VA. Mendelian inheritance in man. Catalogs of autosomal dominant, autosomal recessive, and $X$ linked phenotypes. 10th ed. Baltimore: The Johns Hopkins phenotypes. 10th ed. Baltimore:

4 Wallgren-Pettersson C, Kääriäinen $\mathrm{H}$, Rapola J, et al. Genetics of congenital nemaline myopathy: a study of ten families. $\mathcal{f}$ Med Genet 1990;27:480-7.

5 Laing NG, Majda BT, Akkari PA, et al. Assignment of a gene (NEM1) for dominant nemaline myopathy to chromosome 1. Am f Hum Genet 1992;50:576-83.

6 Jockusch BM, Veldman H, Griffiths GW, van Oost BA, Jennekens FGI. Immunofluorescence microscopy of a myopathy: alpha-actinin is a major constituent of nemaline rods. Exp Cell Res 1980;127:409-20.

7 Beggs AH, Byers TJ, Knoll JHM, et al. Cloning and characterization of two human skeletal muscle alphacharacterization of two human skeletal muscle alphaactinin genes located on

8 Beggs AH, Phillips HA, Kozman H, et al. A (CA)n repea polymorphism for the human skeletal muscle alpha-actinin gene ACTN2 and its localization on the linkage map of chromosome 1. Genomics 1992;13:1314-15.

9 Wallgren-Pettersson C. Congenital nemaline myopathy: a clinical follow-up study of twelve patients. 7 Neurol $S_{C i}$ 1989;89:1-14.

10 Weber JL, May PE. Abundant class of human DNA polymorphisms which can be typed using the polymerase polymorphisms which can be typed using the polyme

11 Lathrop GM, Lalouel JM, Julier C, Ott J. Strategies for multilocus linkage analysis in humans. Proc Natl Acad Sci USA 1984;81:3443-6. 